\title{
Roadmap to sustainable warehouse
}

\author{
Magdalena Malinowska ${ }^{1,}{ }^{*}$, Andrzej Rzeczycki ${ }^{1}$, and Mariusz Sowa $^{1}$ \\ ${ }^{1}$ University of Szczecin, Faculty of Management and Economics of Services, Logistics Department, \\ 8 Cukrowa St., 71-004 Szczecin, Poland
}

\begin{abstract}
Heading towards sustainable logistic is a popular tendency. However it is widely discussed in case of supply chain, there are many studies concerning warehouse and warehousing. Introducing and developing sustainable warehouse solutions is often a challenge. In the article, the authors analysed the literature sources (scientific publications and professional studies) to indicate directions and changes in technological, managerial, social, environmental and economic aspects of warehouse functioning that are required to go forward to sustainable tendency. To summarize the studies, the application model presenting assessment of the status of sustainable warehouse is proposed. The purpose of this model is to provide policy-makers insights to identify actual state of warehouse in a company and perspectives of its development.
\end{abstract}

\section{Introduction}

The understanding of the concept of sustainable development was presented for the first time over 300 years ago by the German scientist Hans Carl von Carlowitz, and referred to as "Nachhaltigkeit". The term referred to forests and was related to the way of forest crop management or tree felling management, in such a way as to allow continuous forest recreation. In 1713, von Carlowitz ordered the reconstruction of the forests under his jurisdiction and introduced the principles of regulated and future-oriented management of natural resources. Soon his model was adopted in forestry of all over Germany, then it became an example for the whole world, which finally led to the translation of the term "Nachhaltigkeit" into English - Sustained Yield Forestry. It was not until the 1980s, when the term "sustainable" was adopted by ecologists and went beyond the framework of forestry.

Today, the concept of sustainable development is used in the sense of the universal, encompassing not only economic, but also environmental and social [1]. In the UK, the Department of the Environment, Transport and the Regions (DETR), defined in 1999 the concept of sustainable development (sustainability) as the social progress that recognizes simultaneously divergent needs and provides effective protection of the environment through rational use of natural resources and maintaining a high, stable level of development and employment [2]. Sustainable development is thus understood as an idea, assuming the progress of civilization present generation, which does not reduce the ability to meet the needs of future generations [3]. In relation to the construction sector, this means

\footnotetext{
*Corresponding author: magdalena.malinowska@,wzieu.pl
} 
reducing the impact on the natural environment through the use of renewable materials (or virtually inexhaustible) throughout the whole life cycle of the building, i.e. design, construction, operation and demolition. The idea of sustainable development in architecture also includes pro-social aspects, focusing on creating optimal health, aesthetic and social conditions for people to stay. Thus, in the case of sustainable buildings, a whole range of criteria must be taken into account that affect all three inseparable elements of sustainability: ecology, economics, and society [4].

Office of the Federal Environmental Executive defines a green building as a practice to increase the efficiency of energy, water and materials use by buildings and a reduction of the negative impact of a building on human health and the environment through better localization, design, construction, operation, maintenance and disposal in the whole life cycle of the building. This definition emphasizes the direct impact on the environment (including the work environment) and the reduction of consumption of the media in general. The definition of Sustainable Buildings Industry Council is similar, defining a sustainable building as a building whose location, design, construction, use, maintenance and demolition are carried out efficiently in terms of energy, water and materials, while providing a healthy, efficient and comfortable indoor environment and long-term benefits for owners, users and society as a whole. The apparent similarity of the definitions results from the interchangeable use of the terms "green" and "sustainable". Some definitions even combine both terms: a green building and / or a sustainable building and define it as design, construction and operational practices that significantly reduce resource consumption and environmental impact. According to the Building Science Corporation, the green building is a label for processes of designing and constructing the buildings, aimed at creating buildings that are less harmful to the environment and users than most buildings currently under construction, focusing on gradually solving the problems known from current practice. This is confirmed by the definition of a "highly efficient green building" as a building that, compared to similar buildings (among others) reduces the consumption of energy, water and other materials, improves the quality of indoor conditions or reduces the negative impact on the environment [3].

In order to achieve the title of a green or sustainable building, or in a particular case, a warehouse, the same solutions are applied, but in the case of a sustainable warehouse, a greater emphasis is placed on integration and synergy. In accordance with solutions point of view, the differences between a green and sustainable warehouse are getting blurred. However, the warehouse as a building is characterized by additional aspects that distinguish it from other buildings - the warehouse process is carried out in it and its uninterrupted course is a condition for the use of possible sustainable modifications. In addition, storage and handling technologies are used in each warehouse and their efficiency is another condition for the implementation of green technologies. Solutions disturbing the warehouse process or reducing the efficiency of the use of warehouse technologies are not acceptable from the logistics point of view. A sustainable warehouse means integration, management and balance of economic and social aspects, and in particular the environmental facilities and processes [3], although these aspects should be supplemented with technological and organizational aspects. Paraphrasing the definition of sustainable development, a sustainable warehouse is a warehouse balancing between the organizational, technological, economic and social functioning that is correct in terms of organization, and the impact on the natural environment. At the same time, organizational and technological aspects are causative aspects, while ecological and social aspects are the results of their operation, taking into account economic efficiency. Finally, a sustainable warehouse can be defined as a set of organizational and technological solutions aimed at efficient realization of the warehouse process, while maintaining the highest social standards, minimizing the environmental impact with regard to financial efficiency. 
The aim of this article is to present a model for assessing the level of sustainable warehouse as well as indicate the activities, that may increase the grade of selected criteria, that are taken into account within the model.

\section{Methodology}

The model presented in the article was created using one of the methods of multicriteria optimization of the decision named the characteristic objects method (COMET). The advantages of the method include eliminating the problem of rank reversal (decision alternatives may have different assessments depending on the choice of other alternatives in the problem taking under consideration) through the use of fixed reference points, and additionally allows to test the correctness of operation of the obtained model [5]. The method, however, is based on the opinions of experts, so the basic disadvantages include the difficulty in selecting experts and the assumption that the compliance of the opinions expressed is synonymous with their truthfulness and accuracy.

The method of characteristic objects is based on the theory of fuzzy sets [6-9] consisting of five steps presented by W. Sałabun [10]:

1. Defining the problem space by defining criteria and a set of fuzzy numbers for each of the criteria.

2. Generating characteristic objects using a Cartesian product

3. Ranking and evaluation of characteristic objects using the Matrix of Expert Judgment.

4. Conversion of each characteristic object and preference value into a fuzzy rule.

5. Inferencing in a fuzzy model and final ranking.

In order to define the space of the problem, the identification of the factors influencing on the warehouse sustainability level was carried out. The authors made a critical review of the scientific literature, as well as the applied best practices and requirements taken into account in LEED and BREEAM building assessment systems. The evaluation criteria were selected and the appropriate scales for each of them was proposed using the fuzzy numbers. The process of applying the fuzzy number for each criteria was performed based on the experts' opinions.

Evaluation of experts through the use of fuzzy numbers was presented in the form of different distributions of membership function [8]. The simplest membership functions are formed using straight lines. Due to their simple formulas and computational efficiency, both triangular and trapezoidal membership function have been used extensively, especially in real-time implementations. However, since the membership function are composed of straight line segments, they are not smooth at the corner points specified by the parameters. [11-12]. The most common types of membership functions are: triangular, trapezoidal, Gaussian, generalized bell, $\pi$ - shaped and $s$ - shaped membership function. The list of membership function is by no means exclusive; other specialized function can be created for specific applications if necessary. In particular, any type of continuous probability distribution functions can be used as an membership function [13-14].

In the proposed model the authors used in particular triangular and trapezoidal membership functions. It allowed to express each criteria in fuzzy numbers, and then use the presented steps of the method to elaborate the final model.

\section{Results}

The literature analysis shows, that there are many publications concerning the practical aspects of sustainable warehouse [15-18] as well as the modeling approaches of this issues 
[19-24]. Available sources empathize the importance of the sustainable warehouse, distinguish the factors affecting the level of sustainable development and indicate the level of a sustainable warehouse, which is the basis for the assessment and certification.

In the article, the authors propose to use the characteristic object method to assess the level of a sustainable warehouse. Moreover, within each of the distinguished criteria, which are the basis for the assessment, the activities aimed at improving the infrastructure, processes and management methods towards a sustainable warehouse are indicated (Table 1.).

On the basis of the literature review 22 criteria were identified: 1 . the use of light lighting control devices, 3 . the light of the skylights, 4 . the light surface of the skylights , 6 . the use of renewable energy, 7. the use of automatic water sources, of environmental protection materials, 12. environmental friendly plot area, 13. level of automation, 14. IT level, 15. effective inventory control, 16. distance reduction during warehouse operations, 17. employees 'training regarding to recycling and sustainable development, 18. employees' training regarding to the handling of equipment, 20. recycling of packaging and returns, 21. organization of employee-friendly zones, 22. applying of the health and safety policy. The criteria (variables) were the basis for elaboration of a linguistic knowledge base, which allows to reasoning in terms of the level of sustainable warehouse.

A scale was indicated for each variable and was expressed in natural language using a set of fuzzy numbers. An example characteristic of the adopted scale with the assigned linguistic values for the environmental friendly plot area variable is shown in figure 1 . The variable reflects the percentage share of green areas on the plot. For subsequent percentage values the linguistic values were assigned as following \{small, medium, large\}. It means that, i.e. a range of $7-10 \%$ of the plot area is reflected by the medium value in linguistic scale. The prepared linguistic scale is the basis for creating the subsequent steps of ranking and evaluation using the expert assessment matrix.

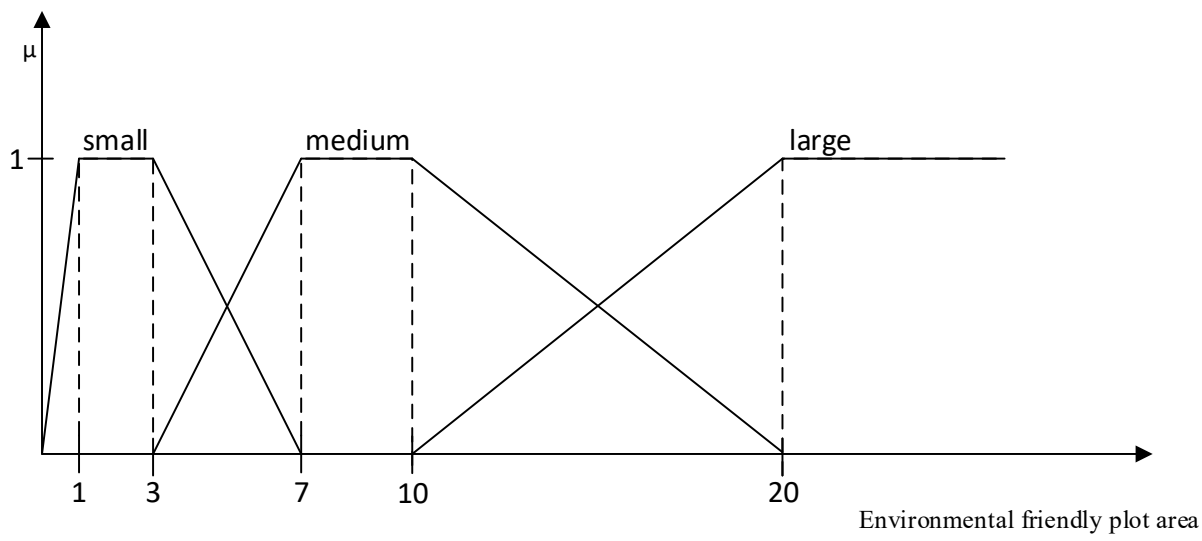

Fig. 1. The characteristic of trapezoidal set of fuzzy numbers for the environmental friendly plot area criteria (source: own elaboration).

Identifying the scale for a variables and expressing it in the form of a natural language, allows, after making the appropriate aggregations of the criteria, to obtain a result which for the considered problem is defines as the level of sustainable warehouse (figure 2). The elaboration of a knowledge base using a linguistic scale for distinguished criteria, as well as appropriate aggregations cause that the research issue is considered without taking into account the difficulties associated with the multidimensional character of the model. In the analyzed model, 19 aggregations (consist of 2 or 3 variables) were made taking into account the hierarchy of the criteria significance on the studied problem. 


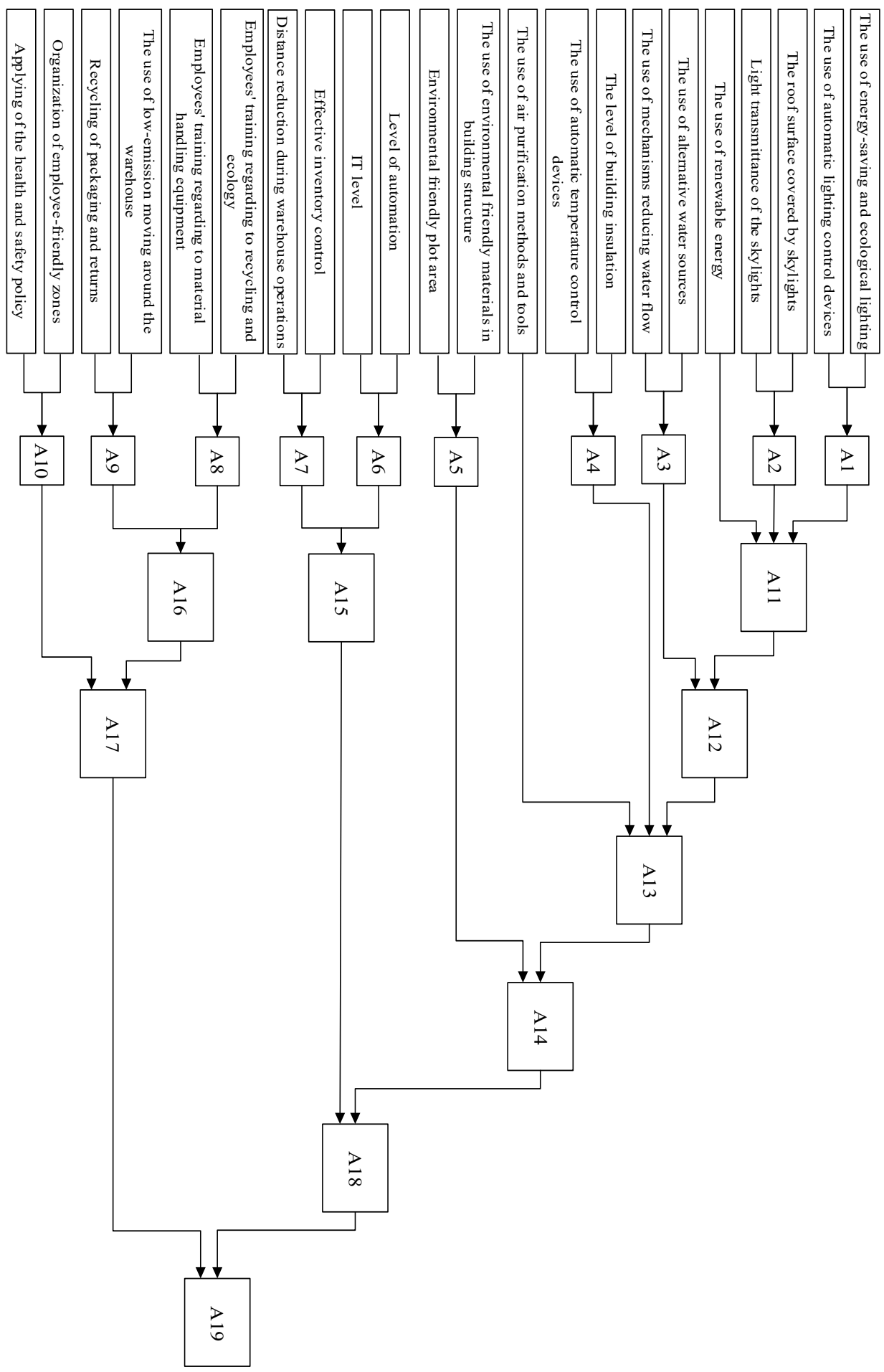

Fig. 2. The concept of the warehouse sustainability assessment model.

An example of the aggregation defined by the authors for the criteria "the use of energysaving and ecological lighting" and "the use of automatic lighting control devices" is A1: 
"the use of automatic lighting control devices". To determine the aggregate the expert method was used to rank the results reflecting the comparison of each linguistic value combinations of two variables as well as assigning linguistic values for the new created criteria.

The implementation of subsequent aggregations leads to achieving the final value of the evaluation - the level of sustainable warehouse, which is expressed as a combination of A17 and A18 aggregates. The obtained result will be presented in linguistic form. Using the model prepared in accordance with the method of characteristic objects, it is possible to evaluate real warehouses and, based on the obtained results, present the level of sustainable warehouse for each object in the natural language (A19 aggregate): unsustainable, very poorly sustainable, poorly sustainable, moderately sustainable, highly sustainable, very highly sustainable.

The proposed approach to determine the level of a sustainable warehouse on the basis of the selected criteria, may also constitute the basis for improving the values of this criteria through appropriate activities. A list of activities that constitute the roadmap, how to gain the better level of the sustainable warehouse are presented in table 1. Additionally, there are underline the basic benefits taking into account such issues as economy, social aspect, ecology, technology and organizational issues.

Tab.1. Criteria for warehouse assessment in the aspect of sustainable functioning

\begin{tabular}{|c|c|c|}
\hline Criteria & $\begin{array}{l}\text { Activieties to achieve the better results of } \\
\text { the evaluation criteria }\end{array}$ & $\begin{array}{c}\text { Advantages of the } \\
\text { application }\end{array}$ \\
\hline $\begin{array}{l}\text { The use of energy- } \\
\text { saving and ecological } \\
\text { lighting }\end{array}$ & $\begin{array}{l}\text { - use of certified energy-saving lighting } \\
\text { (eg LED) with high intensity (at least } \\
4000 \text { lux) } \\
\text { - reduction of light bulbs containing } \\
\text { mercury compounds }\end{array}$ & $\begin{array}{l}\text { - reduction of operating } \\
\text { costs } \\
\text { - reduction of electricity } \\
\text { consumption }\end{array}$ \\
\hline $\begin{array}{l}\text { The use of automatic } \\
\text { lighting control } \\
\text { devices }\end{array}$ & $\begin{array}{l}\text { - application of motion sensors } \\
\text { - clock control lighting } \\
\text { - use of twilight switches }\end{array}$ & $\begin{array}{l}\text { - reduction of operating } \\
\text { costs } \\
\text { - reduction of electricity } \\
\text { consumption } \\
\end{array}$ \\
\hline $\begin{array}{l}\text { The roof surface } \\
\text { covered by skylights }\end{array}$ & - installation of roof skylights & $\begin{array}{l}\text { - improving working } \\
\text { conditions and } \\
\text { increasing employee } \\
\text { concentration }\end{array}$ \\
\hline $\begin{array}{l}\text { Light transmittance in } \\
\text { skylights }\end{array}$ & $\begin{array}{l}\text { - application of high transparency glazing } \\
\text { (in accordance with the requirements of } \\
\text { stored products) }\end{array}$ & $\begin{array}{l}\text { - reduction of energy } \\
\text { consumption costs } \\
\text { - improving the working } \\
\text { atmosphere and } \\
\text { increasing the } \\
\text { concentration of } \\
\text { employees }\end{array}$ \\
\hline $\begin{array}{l}\text { The use of renewable } \\
\text { energy }\end{array}$ & $\begin{array}{l}\text { - assembly of solar panels } \\
\text { - use of wind energy } \\
\text { - installation of a heat pump }\end{array}$ & $\begin{array}{l}\text { - reduction of operating } \\
\text { costs } \\
\text { - reduction of energy } \\
\text { consumption }\end{array}$ \\
\hline $\begin{array}{l}\text { The use of alternative } \\
\text { water sources }\end{array}$ & - use of rainwater for irrigation of plants & $\begin{array}{l}\text { - reduction of operating } \\
\text { costs }\end{array}$ \\
\hline $\begin{array}{l}\text { The use of } \\
\text { mechanisms reducing } \\
\text { water flow }\end{array}$ & $\begin{array}{l}\text { - taps with a temporary switch } \\
\text { - assembly of low-bandwidth white } \\
\text { assembly devices (taps, toilets, showers, } \\
\text { etc.) }\end{array}$ & $\begin{array}{l}\text { - reduction of water } \\
\text { consumption } \\
\text { - reduction of operating } \\
\text { costs }\end{array}$ \\
\hline The level of building & - creating "green roofs" & - noise reduction \\
\hline
\end{tabular}




\begin{tabular}{|c|c|c|}
\hline Criteria & $\begin{array}{c}\text { Activieties to achieve the better results of } \\
\text { the evaluation criteria }\end{array}$ & $\begin{array}{c}\begin{array}{c}\text { Advantages of the } \\
\text { application }\end{array} \\
\end{array}$ \\
\hline insulation & $\begin{array}{l}\text { - the use of building materials for thermal } \\
\text { and anti-condensation insulation of } \\
\text { walls, floors and roofs of the warehouse }\end{array}$ & $\begin{array}{l}\text { - reduction of energy } \\
\text { consumption } \\
\text { - reduction of operating } \\
\text { costs }\end{array}$ \\
\hline $\begin{array}{l}\text { The use of automatic } \\
\text { temperature control } \\
\text { devices }\end{array}$ & $\begin{array}{l}\text { - air-conditioning installation with } \\
\text { thermostats } \\
\text { - installation of temperature sensors and } \\
\text { weather regulators } \\
\end{array}$ & $\begin{array}{l}\text { - improvement of } \\
\text { working conditions } \\
\text { - reduction of warehouse } \\
\text { losses }\end{array}$ \\
\hline $\begin{array}{l}\text { The use of air } \\
\text { purification methods } \\
\text { and tools }\end{array}$ & $\begin{array}{l}\text { - installation of air vents and filters } \\
\text { - assembly of actuators for automatic } \\
\text { opening of roof skylights }\end{array}$ & $\begin{array}{l}\text { - improvement of } \\
\text { working conditions }\end{array}$ \\
\hline $\begin{array}{l}\text { The use of } \\
\text { environmental } \\
\text { friendly materials in } \\
\text { building structure }\end{array}$ & $\begin{array}{l}\text { - use of low-emission and certified paints, } \\
\text { varnishes, silicones and other sealants, } \\
\text { concrete floors, floor coverings, etc. } \\
\text { - use of soundproofing materials } \\
\text { - use of recycled materials }\end{array}$ & $\begin{array}{l}\text { - reducing the negative } \\
\text { impact of the facility } \\
\text { on the environment and } \\
\text { the health of } \\
\text { employees }\end{array}$ \\
\hline $\begin{array}{l}\text { Environmental } \\
\text { friendly plot area }\end{array}$ & $\begin{array}{l}\text { - construction of green roofs } \\
\text { - planting non-invasive and non-irrigating } \\
\text { plants } \\
\text { - ensuring the biodiversity of the applied } \\
\text { flora }\end{array}$ & $\begin{array}{l}\text { - improvement of } \\
\text { working conditions } \\
\text { - increasing the value of } \\
\text { the plot (improvement } \\
\text { of the view) } \\
\text { - improvement of the } \\
\text { local environment } \\
\text { condition }\end{array}$ \\
\hline Level of automation & $\begin{array}{l}\text { use of robots, automatic conveyors, self- } \\
\text { propelled carriages, automatic foil } \\
\text { presses, etc. } \\
\text { - use of mobile terminals and picking } \\
\text { zones }\end{array}$ & $\begin{array}{l}\text { - increase in the } \\
\text { efficiency of processes } \\
\text { - improvement of } \\
\text { working conditions }\end{array}$ \\
\hline IT level & $\begin{array}{l}\text { - application of IT systems optimizing } \\
\text { warehouse work (eg. WMS, WCS, ERP, } \\
\text { SCM, etc.) } \\
\text { - limitation of paper documentation }\end{array}$ & $\begin{array}{l}\text { - increase in the } \\
\text { efficiency of processes } \\
\text { - reduction in the use of } \\
\text { paper documents }\end{array}$ \\
\hline $\begin{array}{l}\text { Effective inventory } \\
\text { control }\end{array}$ & $\begin{array}{l}\text { - optimization of the storage strategy } \\
\text { - inventory level optimization } \\
\text { - maximizing the use of storage space }\end{array}$ & $\begin{array}{l}\text { - increasing the } \\
\text { efficiency of } \\
\text { warehouse processes } \\
\text { - better use of storage } \\
\text { space }\end{array}$ \\
\hline $\begin{array}{l}\text { Distance reduction } \\
\text { during warehouse } \\
\text { operations }\end{array}$ & $\begin{array}{l}\text { - optimization of picking routes } \\
\text { - optimization of the distribution of } \\
\text { storage zones and warehouse equipment } \\
\text { - creation of picking zones, picking paths, } \\
\text { consolidation of orders }\end{array}$ & $\begin{array}{l}\text { - increase in work } \\
\text { efficiency }\end{array}$ \\
\hline $\begin{array}{l}\text { Employees' training } \\
\text { regarding to recycling } \\
\text { and sustainable } \\
\text { development }\end{array}$ & $\begin{array}{l}\text { - conducting employee training and cyclic } \\
\text { training } \\
\text { - application of an incentive system to } \\
\text { mobilize employees } \\
\text { - conducting employee training and cyclic } \\
\text { training } \\
\text { - application of an incentive system to } \\
\text { mobilize employees }\end{array}$ & $\begin{array}{l}\text { - lowering the costs of } \\
\text { warehouse processes } \\
\text { - reducing the amount of } \\
\text { waste }\end{array}$ \\
\hline
\end{tabular}




\begin{tabular}{|c|c|c|}
\hline Criteria & $\begin{array}{l}\text { Activieties to achieve the better results of } \\
\text { the evaluation criteria }\end{array}$ & $\begin{array}{l}\text { Advantages of the } \\
\text { application }\end{array}$ \\
\hline $\begin{array}{l}\text { Employees' training } \\
\text { regarding to material } \\
\text { handling equipment }\end{array}$ & $\begin{array}{l}\text { - conducting employee training and cyclic } \\
\text { training } \\
\text { - application of an incentive system to } \\
\text { mobilize employees }\end{array}$ & $\begin{array}{l}\text { - increase in productivity } \\
\text { and work safety } \\
\text { - reduction of warehouse } \\
\text { losses }\end{array}$ \\
\hline $\begin{array}{l}\text { The use of low- } \\
\text { emission moving } \\
\text { around the warehouse }\end{array}$ & $\begin{array}{l}\text { - purchase of low-emission internal } \\
\text { transport equipment } \\
\text { - ecodriving }\end{array}$ & $\begin{array}{l}\text { - reduction of air } \\
\text { pollution } \\
\text { - increase in work } \\
\text { efficiency } \\
\end{array}$ \\
\hline $\begin{array}{l}\text { Recycling of } \\
\text { packaging and returns }\end{array}$ & $\begin{array}{l}\text { - re-use of packaging } \\
\text { - alternative use of packaging } \\
\text { - collection, segregation and re-use of } \\
\text { packaging materials outside } \\
\text { - implementing a refund control and } \\
\text { management system }\end{array}$ & $\begin{array}{l}\text { - lowering the costs of } \\
\text { warehouse processes } \\
\text { - reducing the amount of } \\
\text { waste }\end{array}$ \\
\hline $\begin{array}{l}\text { Organization of } \\
\text { employee-friendly } \\
\text { zones }\end{array}$ & $\begin{array}{l}\text { creation of canteens, kitchens, sanitary } \\
\text { and hygienic rooms, relaxation areas for } \\
\text { employees } \\
\text { - arranging created rooms in places } \\
\text { convenient for employees }\end{array}$ & $\begin{array}{l}\text { - improvement of } \\
\text { working conditions } \\
\text { - increase in employee } \\
\text { productivity }\end{array}$ \\
\hline $\begin{array}{l}\text { Applying health and } \\
\text { safety policy }\end{array}$ & $\begin{array}{l}\text { - security audits } \\
\text { - inspections and controls of used devices } \\
\text { - use of temperature sensors, air quality, } \\
\text { etc. } \\
\text { - use of fire-fighting equipment }\end{array}$ & $\begin{array}{l}\text { - improvement of } \\
\text { working conditions }\end{array}$ \\
\hline
\end{tabular}

\section{Summary}

The article presents the original concept of a model based on the method of characteristic objects (COMET) and dedicated to assessing the level of a sustainable warehouse. The model uses the fuzzy set theory and utilizes the fuzzy numbers and matrix of expert judgement to reduce the multidimensionality of conclusions. The fuzzification was based on the expert opinions.

The authors considered the topic due to the increasing interest of the sustainability in case of buildings, also for the logistic purposes. On the market, there are some certification programs, which allows to assess the level of sustainable buildings (also warehouses), but there are not focused on the specific type of buildings, and are utilized in general. Additionally, the evaluation is a result of sum of points for selected criteria.

The proposed model is a dedicated one and include 22 criteria, which from the authors point of view are significant to assess the level of sustainable warehouse. The selection of criteria is so wide that it gives the opportunity to use the proposed assessment to evaluate both existing and newly-created warehouses. To indicate the way towards higher level of sustainability, the authors additionally proposed activities, which might increase the grade of criteria used in the model. For each criteria the positive economical, ecological and social effects were distinguished to motivate for applying the solutions.

Due to the complexity of the whole model, in the article was presented the crucial assumptions for its creation and the applied approach. The model is currently reviewed taking into account the correctness of fuzzification and proposed aggregations. The authors are also preparing the scenario of practical assessment of the warehouses to verify the correctness of the model. 


\section{References}

1. A. Ciżmowska, Problems of sustainable development, 7, 2 (2012)

2. A. Płachciak, Ekonomia Conomics, nr 5, 17 (2011)

3. W. Żuchowski, Logistyka, 6 (2014)

4. B. Królczyk, Budownictwo zielone, naturalne, ekologiczne zrównoważone? (Article available on the website:

http://chronmyklimat.pl/projekty/klimapolka/wiadomosci/37/budownictwo-zielonenaturalne-ekologiczne-zrownowazone, 2018)

5. W. Sałabun, Studia Informatica, 38 (878), 145-158 (2015)

6. T.J. Ross, Fuzzy Logic with Engineering Applications (John Wiley \& Sons, Chichester, 2010)

7. A. Piegat, Fuzzy Modeling and Control (Springer-Verlag, New York, 2001)

8. A. Piegat, Modelowanie i sterowanie rozmyte (Akademicka Oficyna Wydawnicza Exit, Warszawa, 2015)

9. H.J. Zimmermann, Fuzzy Set Theory - and Its Applications (Kluwer, Boston, 2001)

10. W. Sałabun, Journal of Multi-Criteria Decision Analysis 22 (1-2), 37-50 (2014)

11. G.J. KlirfBu Yuan, Fuzzy Sets And Fuzzy Logic (Prentice Hall, 1995)

12. W. Li-Xin, A Course in Fuzzy Systems and Control (Prentice-Hall International, Inc. International Edition, 1997)

13. S.V. Shinde, U.V. Kulkarni, Modified Fuzzy Hyperline-Segment Neural Network For Classification With Mixed Attribues, Fifth International Conference on Computing, Communications and Networking Technologies (ICCCNT), IEEE, 1-7 (2014)

14. O.A.M. Ali, A.Y. Ali, B.S. Sumait, International Journal of Emerging Engineering Research and Technology, 3, 3, 76-83 (2015)

15. A. Vorbrodt, Zielony magazyn (Article available on the website: https://www.log24.pl/artykuly/zielony-magazyn,5279, 2018)

16. W. Labs, Food Engineering, 1, (2012)

17. P.A. Trunick, World Trade, 100, 40-43 (2013)

18. Ch. Xu, W. Xiaojun, K. Vikas, K. Niraj, Journal of Cleaner Production, 139, 894- 904 (2016)

19. T.W. Amjed, N.J. Harrison, A model for sustainable warehousing: from theory to best practices, in: A.E. Avery (ed.), International DSI and Asia Pacific DSI Conference proceedings, p. 1892-1919 (2013)

20. K. Tan, A.M. Daud, D. Sundaram, Sustainable warehouse management modelling, in: S. Mann, M. Lopez (eds.), 21st Annual Conference of the National Advisory Committee on Computing Qualifications (NACCQ), Auckland, New Zealand, 109$115(2008)$

21. B. Gallotta, J.A. Garza-Reyes, T. Anosike, M.K. Lim, I. Roberts, A conceptual framework for the implementation of sustainability business processes, Proceedings of the 27th Production and Operations Management Society (POMS), Orlando, FL., US, May 6-8 (2016)

22. A.M. Daud, D. Sundaram, Decision Support Systems, 53, 611-624 (2012)

23. K. Tan, A.M. Daud, D. Sundaram, Business Process Management Journal, 16, 5, 871$886(2010)$

24. F. Boenzi, S. Digiesi, F. Facchini, G. Mossa, G. Mummolo, Sustainable Warehouse Logistics: a NIP Model for non-road vehicles and storage configuration selection, XX Summer School "Francesco Turco - Operational, Excellence, Experiences", 263-270 (2015) 